\title{
Dendritic Cells: Arbiters of Immunity and Immunological Tolerance
}

\author{
Kanako L. Lewis and Boris Reizis \\ Department of Microbiology and Immunology, Columbia University Medical Center, New York, \\ New York, 10032 \\ Correspondence: bvr2101@columbia.edu
}

Dendritic cells (DCs) link innate immune sensing of the environment to the initiation of adaptive immune responses. Given their supreme capacity to interact with and present antigen to T cells, DCs have been proposed as key mediators of immunological tolerance in the steady state. However, recent evidence suggests that the role of DCs in central and peripheral T-cell tolerance is neither obligate nor dominant. Instead, DCs appear to regulate multiple aspects of T-cell physiology including tonic antigen receptor signaling, priming of effector T-cell response, and the maintenance of regulatory T cells. These diverse contributions of DCs may reflect the significant heterogeneity and "division of labor" observed between and within distinct DC subsets. The emerging complex role of different DC subsets should form the conceptual basis of DC-based therapeutic approaches toward induction of tolerance or immunization.

n 2011, the late Ralph Steinman was awarded the Nobel Prize in Physiology or Medicine for his role in the discovery of dendritic cells (DCs) and of their importance in initiating the adaptive immune response. Although DCs were first observed in the skin by Paul Langerhans more than 100 years before his work, Steinman and Zanvil Cohn were the first to show the unique function of DCs. DCs are key sentinel cells that possess distinct "stellate" morphology and unparalleled ability to stimulate naïve $\mathrm{T}$ cells (Steinman 2007). Subsequent work has established that DCs primarily serve as a bridge between the innate and adaptive immune systems without engaging directly in effector functions. Such specialization in sentinel activity at the expense of effector function sets DCs apart from other immune cell types, and it should guide our understanding of DC biology and potential applications.

From the early in vitro studies (Knight et al. 1982) to more recent intravital microscopy (Shakhar et al. 2005), DCs have been observed to continuously interact with $\mathrm{T}$ cells even in the absence of infection. Indeed, DCs bearing self-antigen have been shown to interact with $\mathrm{T}$ cells in the steady state (Scheinecker et al. 2002). Thus, DCs represent obvious candidates to enforce peripheral T-cell tolerance by continuously presenting self- or innocuous antigens (Ag) to T cells in the absence of costimulation and/or activating cytokines. This "tolerogenic" role of DCs could therefore be used as a therapeutic tool to induce or restore tolerance as necessary

Editors: Diane J. Mathis and Alexander Y. Rudensky

Additional Perspectives on Immune Tolerance available at www.cshperspectives.org

Copyright (C) 2012 Cold Spring Harbor Laboratory Press; all rights reserved; doi: 10.1101/cshperspect.a007401

Cite this article as Cold Spring Harb Perspect Biol 2012;4:a007401 
in autoimmune diseases, allergy, etc. (Steinman et al. 2003).

As discussed below, the important contribution of DCs to T-cell tolerance has been confirmed by independent approaches such as genetic or antibody-mediated Ag targeting to DCs. However, the role of DCs in both immunity and tolerance appears complex and highly dependent on genetically and functionally distinct DC subsets. Although extensive "division of labor" exists between and within these subsets, the existence of a unique tolerogenic DC subset or state remains in question. Furthermore, genetic ablation studies revealed that DCs play an essential role in T-cell physiology yet appear largely dispensable for central or peripheral tolerance. This may create significant hurdles to the tolerogenic applications of DCs; on the other hand, they represent supreme candidates in "tolerance-breaking" applications such as antitumor vaccination.

\section{LINEAGE AND SUBSETS}

DCs-a Common Cell Lineage

DCs are present throughout the body, including environmental interfaces such as the intestine, filtering organs, and lymphoid organs (Merad and Manz 2009). These cells can be broadly categorized into two classes: classical or conventional DCs (cDCs) and plasmacytoid DCs ( $\mathrm{pDCs}$ ). The cDCs are highly effective at Ag presentation and T-cell stimulation, even in the absence of intentional activation (Steinman 2012). The pDCs are specially equipped for the secretion of type I interferon (interferon $\alpha / \beta$, IFN-I) and other cytokines (Liu 2005); they present Ag inefficiently in the steady state but are fully capable of Ag presentation after pathogeninduced activation (Villadangos and Young 2008). Thus, both DC classes share essential DC functions such as highly efficient pathogen recognition, lack of obvious effector function, and the capacity to mobilize and activate multiple innate and adaptive immune cell types.

Recent evidence supports the definition of DCs as a distinct immune cell lineage that includes pDCs, cDCs, and subsets thereof (Geiss- mann et al. 2010; Liu and Nussenzweig 2010). Progenitor cell populations giving rise to all DC subsets have been identified in the bone marrow, such as the common dendritic cell progenitor (CDP) (Naik et al. 2007; Onai et al. 2007). The development of CDP and its DC progeny is regulated by cytokine Flt3 ligand (Flt3L) and its receptor Flt3, and several transcription factors such as PU.1 and IRF8 are required in multiple DC subsets and/or developmental stages (Fig. 1) (Belz and Nutt 2012). The affiliation of pDCs with the DC lineage has been controversial, given that pDCs lack several essential DC features such as dendritic morphology and high MHC class II expression (Reizis et al. 2011). Moreover, unlike cDCs that undergo terminal differentiation in the periphery, pDCs complete their development in the bone marrow. However, this has been recently attributed to the role of a specific transcription factor, E2-2, in $\mathrm{pDC}$ development. The induction of E2-2 in DC progenitors diverts pDCs from the "default" DC pathway and specifies lymphocyte-like morphology and other distinct pDC features (Cisse et al. 2008). Indeed, the loss of E2-2 from mature pDCs causes their full phenotypic and functional conversion into cDC-like cells, further supporting the close genetic relationship between pDCs and cDCs (Ghosh et al. 2010).

\section{SUBSETS AND HETEROGENEITY}

Murine cDCs have been traditionally categorized into two distinct subsets, the $\mathrm{CD}^{+}$ $\left(\mathrm{CD} 103^{+}\right.$in tissues) $\mathrm{DCs}$ and $\mathrm{CD} 11 \mathrm{~b}^{+}$"myeloid" DCs. The $\mathrm{CD}^{+} / \mathrm{CD} 103^{+}$subset appears highly efficient at Ag cross-presentation to cytotoxic $\mathrm{CD} 8^{+} \mathrm{T}$ lymphocytes, which may be particularly important during intracellular infections and tumor surveillance (den Haan et al. 2000). The identification of transcription factor Batf3 as a "master regulator" of the $\mathrm{CD}^{+} /$ $\mathrm{CD} 103^{+}$subset strongly supports its unique genetic identity and functionality as a major $\mathrm{Ag}$ cross-presenting cell type (Hildner et al. 2008). The precise function of $\mathrm{CD}_{11 \mathrm{~b}^{+}} \mathrm{DCs}$ remains less well understood, although they are generally believed to prime $\mathrm{CD} 4{ }^{+} \mathrm{T}$-cell responses (Dudziak et al. 2007). 


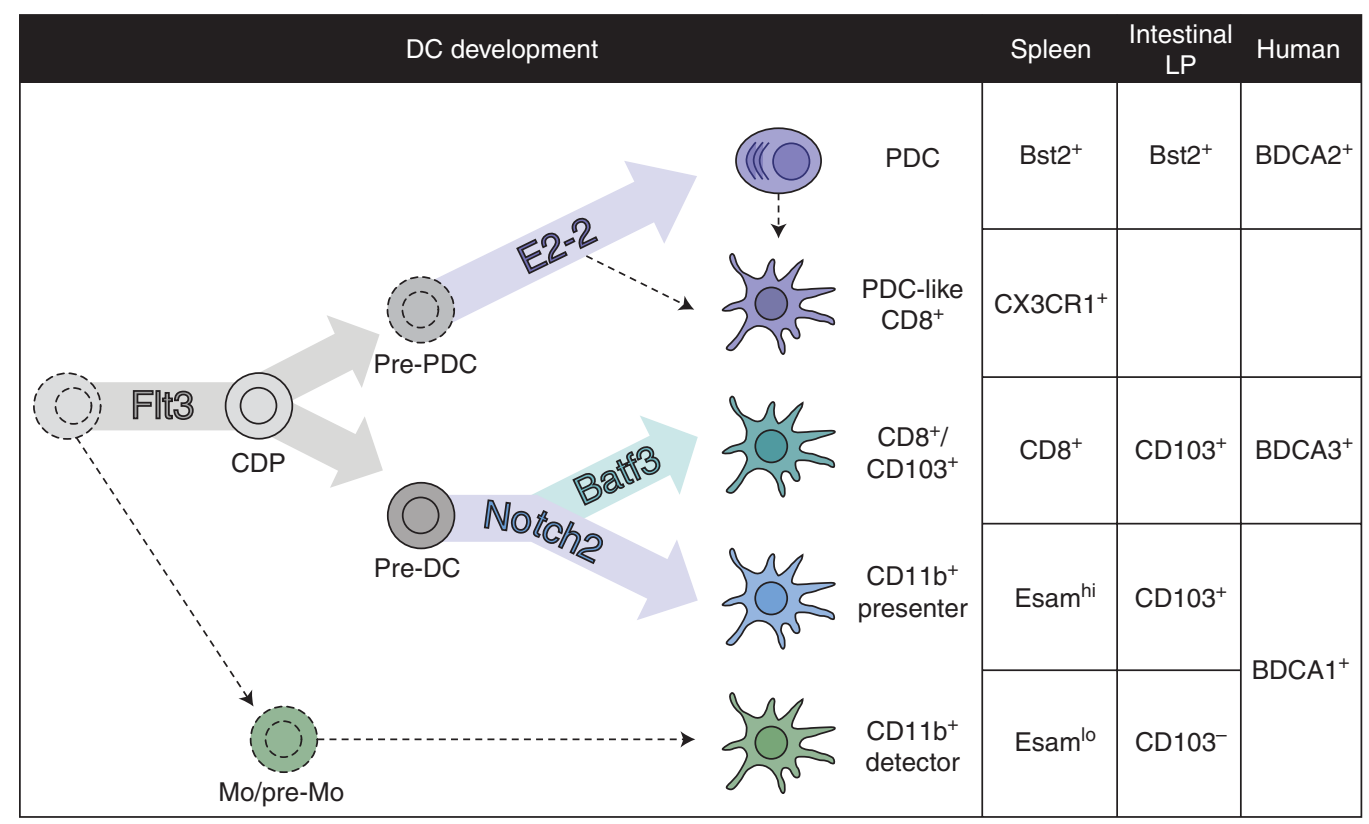

Figure 1. Dendritic cell development and subsets. Shown are functionally and genetically distinct DC subsets identified in the mouse spleen and intestinal lamina propria (LP), their major developmental regulators, and key surface markers. The known counterparts of these subsets in the human peripheral blood are also indicated.

Importantly, the traditional categorization appears to mask the significant heterogeneity that exists within each cDC subset. This is particularly evident in the murine spleen, where cDCs were thought to comprise only two cDC subsets of common origin. However, a significant proportion of splenic $\mathrm{CD} 8^{+}$DCs were found to develop independently of Batf3. The Batf3-independent $\mathrm{CD}^{+}$DCs resemble pDCs in their genetic makeup and dependence on E22 , and may represent "by-products" of pDC development (Bar-On et al. 2010). These cells are unable to cross-present Ag, and their precise function in immunity, if any, remains unclear. Furthermore, splenic CD11b ${ }^{+}$DCs are also comprised of two distinct cell types whose origin and function differ significantly (Lewis et al. 2011; Kasahara and Clark 2012). Some CD11b ${ }^{+}$ DCs develop through a Notch2- and lymphotoxin- $\beta$ receptor-dependent pathway, show typical DC morphology and expression profile, and are required for efficient $\mathrm{CD} 4^{+}$T-cell priming. Conversely, the Notch2-independent CD11b ${ }^{+}$ DCs appear more related to monocytes in their origin and expression profile, and show more robust secretion of inflammatory cytokines (Lewis et al. 2011). These results reveal a "division of labor" not only between DC subsets, but also within each "canonical" DC subset (Fig. 2).

A similar heterogeneity within DC subsets appears to exist in the periphery and is best documented in the intestine. The intestinal lamina propria (LP) includes three $\mathrm{CDC}$ types: the Batf3-dependent $\mathrm{CD} 103^{+} \mathrm{CD} 11 \mathrm{~b}^{-}$DCs that are functionally similar to $\mathrm{CD}^{+}$DCs in lymphoid organs (Edelson et al. 2010); the Notch2-

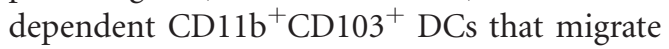
to mesenteric lymph nodes (Bogunovic et al. 2009) and maintain optimal $\mathrm{CD} 4^{+}$effector Tcell numbers in the intestine (Denning et al. 2011; Lewis et al. 2011); and monocyte-derived

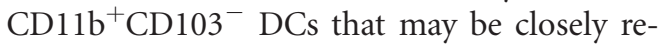
lated to macrophages (Bogunovic et al. 2009; Schulz et al. 2009; Varol et al. 2009). These latter DCs appear to reside continuously in the LP and secrete the inflammatory cytokines that recruit and activate local immune cells. Whereas monocyte-derived DCs may sense the intestinal 
A
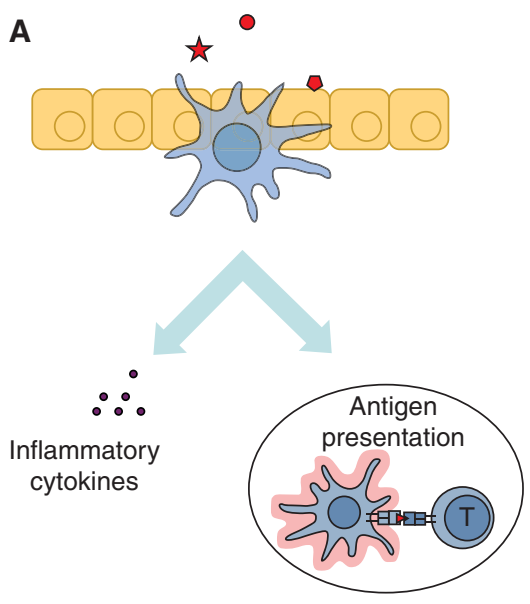

B

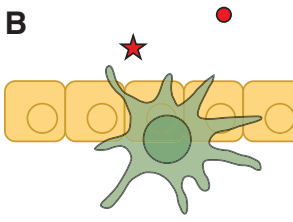

Detector

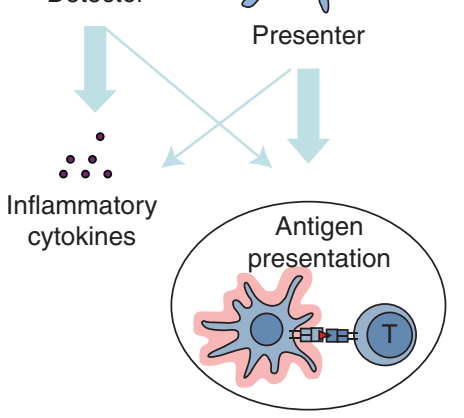

Figure 2. The proposed “division of labor" within dendritic cell subsets. In a traditional view of DC function $(A)$, a single DC detects pathogen, secretes inflammatory cytokines, and migrates to present Ag to naïve T cells. In a revised view $(B)$, physically different DCs within the same subset detect pathogen directly and secrete inflammatory cytokines ("detector" DCs), whereas "presenter" DCs may receive pathogen-derived Ag indirectly through other cells, migrate, and present it ("presenter" DCs).

lumen contents through transepithelial processes (Niess et al. 2005), the $\mathrm{CD}_{103^{+}}{ }^{\mathrm{DC}}$ subsets were recently shown to receive Ag through goblet cell-mediated transport and thereby initiate T-cell responses (McDole et al. 2012). Thus, DCs in tissues such as the intestine are genetically and functionally diverse, and show the same "division of labor" between Ag presentation and cytokine secretion.

\section{DCs IN HUMANS}

Recent work confirmed that major DC subsets are genetically and functionally conserved between mice and humans. This is well illustrated by global gene-expression analysis, which reveals distinct and evolutionarily conserved expression profiles of DC subsets (Crozat et al. 2010b). Indeed, both murine and human pDCs are dependent on E2-2 and express a common set of E2-2-regulated genes (Cisse et al. 2008; Ghosh et al. 2010). Furthermore, several groups have established human BDCA- $3^{+}$DCs as the cross-presenting equivalent to murine Batf3-dependent $\mathrm{CD}^{+} / \mathrm{CD} 103^{+}$DCs (Bachem et al.
2010; Crozat et al. 2010a; Jongbloed et al. 2010; Poulin et al. 2010, 2012). Finally, a major insight into DC biology has been provided by the identification of human patients with DC deficiency (Collin et al. 2011). In particular, patients with mutations in IRF8 lack pDCs, cDCs, and monocytes in circulation (Hambleton et al. 2011). These studies confirm that all DCs and monocytes comprise a unique branch of hematopoiesis, and highlight its evolutionarily conserved transcriptional regulation.

On the other hand, relatively little is known about the heterogeneity and functionality of human DC subsets, particularly in tissues. Several studies in human blood, spleen, and lymph nodes suggest a significant heterogeneity within the BDCA- $1^{+}$DC subset corresponding to

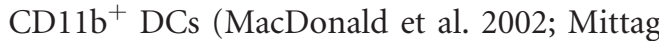
et al. 2011; Segura et al. 2012). The function of these different DC populations and their relationship to the murine counterparts remain unclear. DCs capable of T-cell priming have been identified in the human intestinal LP (Bell et al. 2001), and heterogeneous expression of CD103 has been observed on human MLN 
dendritic cells (Jaensson et al. 2008). An unknown fraction of these may correspond to the Batf3-dependent BDCA-3 ${ }^{+}$subset (Poulin et al. 2012), although it is unclear whether it is uniformly $\mathrm{CD}_{103^{+}}$in humans. Moreover, the human counterpart of T-cell-priming $\mathrm{CD} 103^{+}$ $\mathrm{CD}_{11 \mathrm{~b}}{ }^{+} \mathrm{LP}$ DCs remains to be identified and characterized.

\section{SUBSET HETEROGENEITY: IMPLICATIONS FOR IMMUNITY AND TOLERANCE}

It has been commonly assumed that the same physical cell of a given DC subset detects pathogens through pattern recognition receptors, secretes cytokines, migrates into the T-cell area of lymphoid organs, presents Ag, and directs Tcell priming. A similar scenario of steady-state migration and Ag presentation in the absence of pathogen detection would lead to T-cell tolerance (Fig. 3). However, the newly described heterogeneity of DCs in lymphoid organs and tissues suggests a more nuanced view of DC function. Thus, even within a given DC subset some DCs are more adept at pathogen detection and cytokine secretion in situ, such as the intes- tinal $\mathrm{CD} 11 \mathrm{~b}^{+} \mathrm{CD} 103^{-}$DCs and Notch2-independent splenic CD11b ${ }^{+}$DCs described above. Such DCs are related to monocytes in the origin and/or expression profile (Varol et al. 2010; Lewis et al. 2011), and we here propose to designate them as "detector" DCs. Conversely, a different DC population appears to capture Ag and present it to $\mathrm{T}$ cells after migration to lymphoid organs. The examples include $\mathrm{CD} 11 \mathrm{~b}^{+}$ $\mathrm{CD}_{103}{ }^{+}$intestinal DCs (Bogunovic et al. 2009) and splenic CD11b ${ }^{+}$Esam $^{\text {hi }}$ DCs, both of which are Notch2-dependent (Lewis et al. 2011). These distinct DC populations, which are designated here as "presenters," may benefit from the cytokine milieu created by the "detectors" at the recognition site.

Such "division of labor" between different DCs within each subset has major implications for our understanding and therapeutic use of DC functions. First, the proposed "detector" and "presenter" populations in each lymphoid organ and tissue must be identified and characterized. In animal models, this could be aided by genetic analysis using common regulators such as Notch2, which controls CD11b "presenter" DCs in both spleen and intestine. In humans, this task is further complicated by limited access

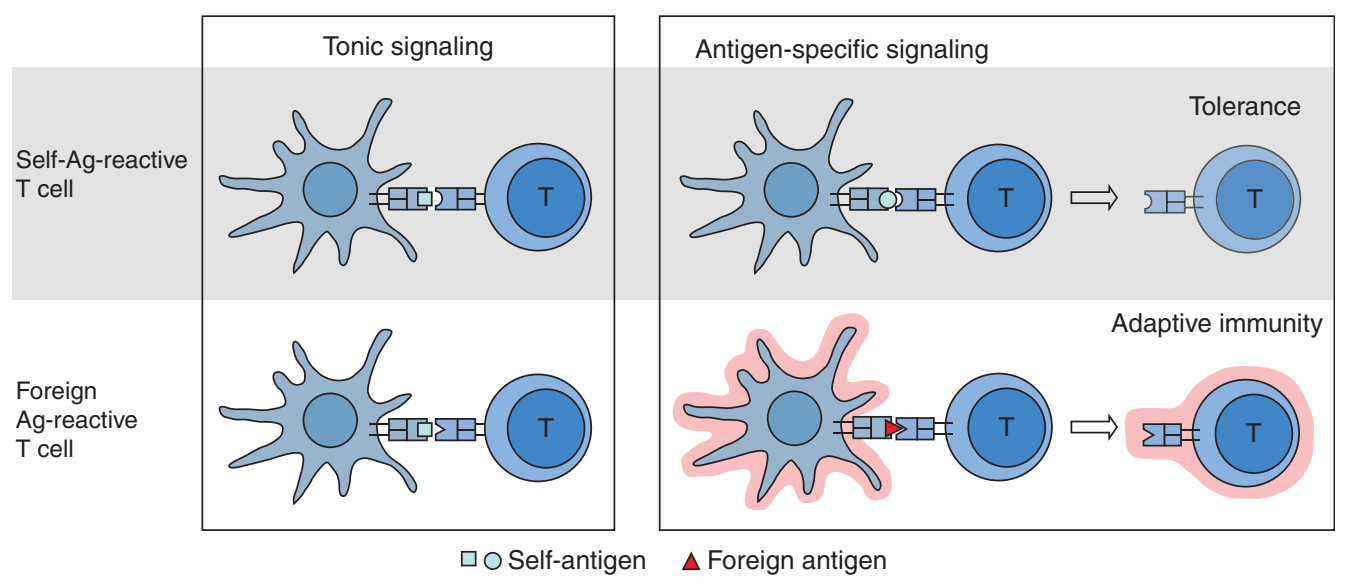

Figure 3. Dendritic cells induce peripheral tolerance or immunity by directing the fate of antigen-specific T cells. Presentation by steady-state DCs of weakly agonistic self-peptides maintains tonic Ag receptor signaling and responsiveness of both normal and self-reactive T cells. Strongly agonistic self-peptides may tolerize self-reactive $\mathrm{T}$ cells when presented by steady-state DCs, whereas foreign peptides presented by activated DCs induce T-cell priming. The loss of DCs would lead to an unresponsive state in both normal and self-reactive T cells, and prevent self- as well as foreign Ag-specific T-cell responses. 
to normal lymphoid organs and tissues, and by extensive variability reflecting individual age, health status, and genetic constitution (Mittag et al. 2011). Nevertheless, knowing the cell that one targets or injects appears as a prerequisite of any rational immunotherapy.

Finally, despite the extensive functional heterogeneity of DCs described above, a dedicated tolerogenic DC subset has not been clearly defined in the steady state. Several proposed tolerogenic or regulatory DC subsets (Zhang et al. 2004; Hadeiba et al. 2008) have not been supported by genetic analysis. For instance, the predicted role of intestinal CD103 ${ }^{+}$DCs in regulatory $\mathrm{T}$-cell $\left(\mathrm{T}_{\text {reg }}\right)$ induction has been called into question by detailed analysis of specific $\mathrm{CD} 103^{+}$ DC subsets (Edelson et al. 2010; Denning et al. 2011; Lewis et al. 2011). Nevertheless, DCs with distinctly tolerogenic properties may arise in artificial genetic systems (Kriegel et al. 2012) or through specific manipulation in vitro (Morelli and Thomson 2007), and thus may be applied as a tolerance-inducing therapeutic tool.

\section{FUNCTION OF DCs IN IMMUNITY AND TOLERANCE}

\section{DCs as Initiators of T-Cell Responses}

The original in vitro observations on the supreme T-cell priming capacity of DCs (Steinman and Witmer 1978) have been strongly supported by genetic models in vivo (Sapoznikov and Jung 2008). For instance, constitutive ablation of cDCs essentially abolishes the priming of allogeneic or Ag-specific T cells in the spleen (Birnberg et al. 2008). Furthermore, certain DC subsets have been shown to be essential in the response to specific pathogens. Thus, the crosspresenting Batf3-dependent DCs contribute to the cytotoxic T-cell response to West Nile and Sendai viruses (Hildner et al. 2008; Edelson et al. 2010). More recently, the same group showed that Batf3-dependent DCs are required for the T-cell-mediated control of Toxoplasma infection, owing to their unique capacity for IL-12 production (Mashayekhi et al. 2011). By comparison, much less is known about the role of $\mathrm{CD} 1 \mathrm{~b}^{+}$DCs in antimicrobial responses, although the Notch2-dependent "presenter" subset appears important for optimal T-cell responses in the spleen and intestine (Lewis et al. 2011). Notably, human patients with IRF8 mutation T80A have a specific reduction of the $\mathrm{CD}_{11 \mathrm{~b}^{+}}$DC population and increased susceptibility to mycobacterial infections (Hambleton et al. 2011). These data suggest a major role of this subset in the immunity to intracellular bacteria, although the extent and mechanism of CD $11 b^{+}$DC reduction remain to be elucidated.

The pDCs secrete IFN-I in response to multiple viruses (Swiecki and Colonna 2010) and are particularly important for IFN-I-mediated innate control of acute cytopathic coronaviruses (Cervantes-Barragan et al. 2007, 2012). Although modest decreases in T-cell responses have been observed after transient ablation of pDCs (Swiecki et al. 2010; Takagi et al. 2011), their overall role in antimicrobial adaptive immunity remained moot. Recently, constitutive pDC ablation through E2-2 targeting revealed the key role of $\mathrm{pDCs}$ in T-cell response to persistent (but not acute) viral infection (Cervantes-Barragan et al. 2012). The pDCs were found to be essential for the priming of virus-specific CD4 ${ }^{+}$T cells, even though MHC class II expression on pDCs was dispensable. Collectively, these results emphasize the role of DCs (including cDCs and pDCs) as a key link between innate immune recognition and adaptive immune response to infections. Furthermore, they show the importance of DC-derived cytokines such as IL-12 and possibly IFN-I in T-cell-mediated immunity, underscoring the likely importance of both "detector" and "presenter" DCs.

\section{The Subversion of DCs by Pathogens}

As almost every functional part of the immune system, DCs are subverted by multiple pathogens. The mobility of DCs appears to be a particular advantage to several pathogens, which "hijack" migrating DCs to facilitate their spread. For example, by infecting pDCs, Toxoplasma may at once evade the IFN-I response and gain access to lymphoid and peripheral tissues (Bierly et al. 2008). Similarly, murine herpesvirus was shown to infect DCs and exploit their motility 
to infect its ultimate target, B cells (Gaspar et al. 2011). Furthermore, cytokine-induced or genetic expansion of DCs increases pathogen burden in infections with intracellular bacteria such as Listeria, underscoring the role of DCs as "sentinels without armament" (Alaniz et al. 2004; Sathaliyawala et al. 2010). Conversely, Batf3-dependent $\mathrm{CD}^{+}$DCs are required to transport Listeria into the splenic white pulp and initiate productive infection (Edelson et al. 2011). Thus, more DCs are not necessarily better, and this caveat must be taken into account in any therapeutic application of DCs.

\section{DCs in Tolerance: Central}

In contrast to their emerging key role in antimicrobial immunity, the role of DCs in the steady-state immune tolerance is still poorly understood. One proposed mechanism whereby DCs might influence central tolerance is selfAg presentation for negative selection of thymocytes. It has been proposed that thymic DCs either directly present or cross-present self-Ags acquired from medullary thymic epithelial cells (mTECs), which express many tissue-specific proteins in an Aire-dependent manner (Gallegos and Bevan 2004). This model is supported by substantial evidence, suggesting that mTECs present self-Ag both directly and through thymic DCs (Hubert et al. 2011; Klein et al. 2011). A variant of this scenario suggests that mTECs recruit thymic DCs in an Aire-dependent manner and thereby facilitate the generation of $\mathrm{T}_{\text {regs }}$ (Lei et al. 2011).

Another proposed mechanism of DC-mediated central tolerance is the recirculation of peripheral DCs into the thymus, which present peripheral self-Ag to induce clonal deletion or $\mathrm{T}_{\text {reg }}$ generation (Proietto et al. 2009). The original demonstration relied heavily on the transfer of large numbers of cytokine-expanded DCs (Bonasio et al. 2006); nevertheless, this and subsequent studies (Proietto et al. 2008) showed that endogenous peripheral DCs migrate into the thymus, and may induce clonal deletion and/or $\mathrm{T}_{\text {regs }}$ for certain model Ag. However, it is unclear whether this mechanism is relevant or operative at all except for special artificial con- ditions. Indeed, constitutive depletion of cDCs did not induce an overt breakdown of central tolerance, and negative selection of model selfAg was found to be normal (Birnberg et al. 2008). The migration-based tolerance induction is even more questionable for pDCs, which were studied in patently artificial conditions (Martin-Gayo et al. 2010; Hadeiba et al. 2012). Furthermore, the proposed Ccr9-mediated migration of murine pDCs into the thymus ( $\mathrm{Ha}$ deiba et al. 2012) cannot operate in humans, because human pDCs do not express Ccr9. Overall, the role of endogenous thymic DCs in central tolerance is plausible but may be relatively subtle or restricted to only certain self-Ag.

\section{DCs in Tolerance: Peripheral}

\section{The Role of Self-Antigen Presentation} by DCs in Tolerance

The first important evidence for the induction of self-tolerance by DCs came from the studies based on Ag targeting in vivo by DC-specific antibodies (Hawiger et al. 2001). This and subsequent studies (Hawiger et al. 2004; Dudziak et al. 2007) documented a profound T-cell tolerization to DC-targeted model Ag in the steady state. Although this approach is elegant and has potential therapeutic implications, some caveats should be kept in mind. First, the specificity of Ag targeting and the identity of targeted DC population have to be precisely defined, and may be critical for the outcome. For example, the DEC205 (Ly75) receptor used to target CD8 ${ }^{+}$ cDCs in the original studies is expressed on a variety of non-DC cell types including some macrophages and granulocytes. Another receptor used for targeting, Dcir2/33D1, is highly DC specific but marks a functionally distinct subset of CD11b ${ }^{+}$cDCs (Lewis et al. 2011; Kasahara and Clark 2012). Second, the identity of the targeted receptor and its potential signaling function may fundamentally influence the outcome of Ag targeting. Indeed, Ag targeting to $\mathrm{pDC}$ using $\mathrm{pDC}$-specific surface molecules SiglecH or Bst2 resulted in T-cell hyporesponsiveness or activation, respectively (Loschko et al. 2011a,b). 
A compelling genetic way to test $\mathrm{Ag}$ presentation by steady-state DCs involved the Cre recombinase-induced expression of model $\mathrm{Ag}$ in DCs in vivo (Probst et al. 2003). Using this approach, it was shown that steady-state presentation of immunodominant virus-derived epitopes by DCs induces a profound $\mathrm{CD}^{+}$ T-cell unresponsiveness that could not be reversed by subsequent challenge with the virus. Further studies elucidated the mechanism of DC-induced T-cell unresponsiveness, including the expression of inhibitory molecules PD-1 and CTLA- 4 on $\mathrm{CD}^{+}{ }^{+} \mathrm{T}$ cells and the induction of $\mathrm{T}_{\text {regs }}$ (Probst et al. 2005; Schildknecht et al. 2010). Collectively, antibody-mediated and genetic Ag targeting suggest that DCs can induce peripheral T-cell tolerance to immunodominant epitopes.

\section{The Impact of DC Loss on Immunity and Tolerance}

Given the evidence described above, it might be expected that the loss of DCs would cause a major breakdown of peripheral tolerance. Surprisingly, animals with Cre-mediated constitutive ablation of cDCs (but not of pDCs) had a relatively normal T-cell compartment without overt hyperactivation (Birnberg et al. 2008). Another study has claimed that constitutive ablation of DCs using a similar system causes autoimmune manifestations (Ohnmacht et al. 2009). However, this study neither documented the full course of the disease, nor provided any evidence for T-cell autoreactivity. It appears likely that the purported "autoimmune" disease was in fact a myeloproliferative syndrome caused by increased serum concentration of Flt3L in the absence of DCs (Birnberg et al. 2008; Hochweller et al. 2009; Bar-On et al. 2011). Similarly, human patients with monocyte and DC deficiency show increased Flt3L levels and the associated myeloproliferation, but no major autoimmune disease (Collin et al. 2011). Finally, constitutive DC ablation on the autoimmunity-prone Fas receptor-deficient background ameliorated rather than exacerbated the lupuslike disease (Teichmann et al. 2010). Thus, steady-state DCs have the ability to toler- ize $\mathrm{T}$ cells, yet their actual role in peripheral tolerance appears neither essential nor dominant.

These findings can be reconciled if one takes into account another major consequence of DC ablation, i.e., the rapid loss of T-cell responsiveness. It has long been recognized that $\mathrm{T}$ cells require "tonic" signaling through the T-cell receptors for their survival and optimal functionality. It was recently shown that DCs provide a major source of such signals, so that DC ablation rapidly causes $\mathrm{T}$ cells to become unresponsive (Hochweller et al. 2010). Thus, autoreactive T-cell clones may receive two kinds of signals from DCs: a tolerizing signal from the self- $\mathrm{Ag}$ and a tonic signal from weakly agonistic MHCpeptide complexes. In the absence of DCs, these $\mathrm{T}$ cells would be relieved of the negative signal but also deprived of the positive signal, resulting in the net absence of self-reactivity. Another important aspect is the nature of self-Ag presented by DCs in the periphery. By analogy to T-cell selection in the thymus, strongly agonistic self-Ag would induce tolerization, whereas weakly agonistic self-peptides would provide a positive tonic signal (Garbi et al. 2010). Not surprisingly, model studies use unusually strong immunodominant epitopes and thus may predominantly reveal the negative signal.

\section{DC-Intrinsic Breach of Immune Tolerance}

Contrary to the loss of DCs, it has been suggested that DC accumulation owing to defective apoptosis causes autoimmunity (Chen et al. 2006; Stranges et al. 2007). However, the DCspecific nature of apoptosis blockade has not been established in either model, and the mechanism of the proposed loss of tolerance in the steady state remains moot. On the other hand, the changes of DC functionality may breach $\mathrm{T}$ cell tolerance and induce inflammation and/or autoimmune manifestations. This was first shown by DC-specific deletion of $\alpha_{\mathrm{V}} \beta_{8}$ integrin, which is required for the activity of immunosuppressive cytokine TGF $\beta$ on T cells (Travis et al. 2007). Similarly, the loss in DCs of A20, a negative regulator of the NF- $\kappa \mathrm{B}$ pathway, causes widespread immune activation and variable manifestations of autoimmunity (Hammer 
et al. 2011; Kool et al. 2011). In the intestine, DC-specific loss of Stat3 or $\beta$-catenin makes DCs refractory to IL-10 or Wnt signaling, respectively, causing or predisposing to inflammation (Manicassamy et al. 2010; Melillo et al. 2010). These studies used broad gene deletion in most DCs including pDCs and all cDC subsets, warranting further investigation into the DC subset(s) responsible for the phenotype.

It should be noted that most of these molecules are general negative regulators of immune activation, and their function is by no means restricted to DCs. Indeed, broad deletion of $\alpha_{V}$ integrins, Stat 3 or A20 from the myeloid lineage may cause even more pronounced inflammation and/or autoimmunity (Takeda et al. 1999; Lacy-Hulbert et al. 2007; Matmati et al. 2011). In that respect, a very interesting case is presented by Blimp-1 (Prdm1), a transcriptional repressor required for B- and T-cell differentiation. The loss of Blimp-1 enhanced IL-6 secretion by DCs and resulted in autoantibody production and other lupus-like manifestations in female (but not male) mice (Kim et al. 2011). This phenotype recapitulates the striking prevalence of lupus in females, and suggests that DCs may be ultimately responsible for this mysterious feature of the disease. Collectively, these results reveal elaborate DC-intrinsic molecular mechanisms that are essential to prevent aberrant DC activation and the ensuing breach of immunological tolerance.

\section{$D C s$ and $T_{\text {regs }}$}

As part of their tolerogenic function, DCs were proposed to mediate the homeostasis of regulatory $\mathrm{T}$ cells in the periphery. Steinman and colleagues showed that DCs can induce $T_{\text {regs }}$ in vitro, especially when combined with strong $\mathrm{T}_{\text {reg-inducing stimuli such as TGF } \beta \text { and retinoic }}$ acid (Yamazaki et al. 2003, 2008; Tarbell et al. 2004; Sela et al. 2011). However, the exact role of DCs in $\mathrm{T}_{\text {reg }}$ induction in vivo remains to be fully elucidated. Indeed, the absence of DCs leads to only a modest reduction in $\mathrm{T}_{\text {reg }}$ numbers (Birnberg et al. 2008; Darrasse-Jeze et al. 2009), although DCs were necessary for homeostatic proliferation of $\mathrm{T}_{\text {regs }}$ after their depletion (Suff- ner et al. 2010). The contribution of DCs to $\mathrm{T}_{\text {res }}$ maintenance is mediated through the costimulatory molecules CD80/CD86 expressed on DCs (Bar-On et al. 2011). However, when separated from myeloproliferation caused by DC loss, the reduction of $\mathrm{T}_{\text {regs }}$ does not cause spontaneous autoimmunity or lymphocyte hyperactivation (Bar-On et al. 2011). Similar observations have been made in humans with DC and monocyte deficiency (Collin et al. 2011).

Conversely, it was shown that administration of Flt3L leads to an expansion of both DCs and $\mathrm{T}_{\text {regs }}$ (Darrasse-Jeze et al. 2009; Swee et al. 2009; Collins et al. 2011). In particular, Flt3L treatment led to the expansion of $\mathrm{CD}_{103}{ }^{+} \mathrm{CD} 11 \mathrm{~b}^{-}$and $\mathrm{CD}_{103}{ }^{+} \mathrm{CD} 11 \mathrm{~b}^{+}$DCs in the intestinal LP and increased $\mathrm{T}_{\text {reg }}$ numbers, correlating with reduced severity of ileitis in a Crohn's disease-prone mouse (Collins et al. 2011). Furthermore, Flt3L administration also enhanced survival from graft-versus-host disease, presumably through the induction of $\mathrm{T}_{\text {regs }}$ (Swee et al. 2009). These studies convincingly documented $\mathrm{T}_{\text {reg }}$ expansion and overall tolerogenic environment following Flt3L administration in vivo, which has been interpreted as a simple consequence of increased DC numbers. However, this explanation is subject to major caveats. For instance, Flt3L causes skewing of DC populations toward the $\mathrm{CD} 8^{+} \mathrm{cDC}$ lineage (O'Keeffe et al. 2002; Vollstedt et al. $2004)$; in addition, it may expand non-DCs including various myeloid cell types. Most importantly, Flt3L-expanded DCs may not be functionally equivalent to the steady-state DCs, e.g., owing to Flt3L-induced mTOR signaling (Sathaliyawala et al. 2010). Thus, the increase in DC numbers as a necessary and sufficient cause of $\mathrm{T}_{\text {reg }}$ expansion remains to be formally proven.

Interestingly, DC cell numbers increase after depletion of $\mathrm{T}_{\text {regs }}$, suggesting that $\mathrm{T}_{\text {regs }}$ regulate DC expansion (Kim et al. 2007). It has been shown that DC expansion in the absence of $\mathrm{T}_{\text {regs }}$ occurs through a Flt3-dependent pathway (Liu et al. 2009). Thus, $\mathrm{T}_{\text {regs }}$ may participate in feedback control of DC activity through a yet unknown Flt3-dependent mechanism. The $\mathrm{pDCs}$ have been implicated into $\mathrm{T}_{\text {reg }}$ induction in several specialized models such as organ 
transplantation (Ochando et al. 2006) and neural inflammation (Irla et al. 2010). On the other hand, pDC-deficient animals have normal $\mathrm{T}_{\text {reg }}$ compartments and no apparent T-cell activation or autoimmunity (Cervantes-Barragan et al. 2012; K Lewis, unpubl.). Altogether, current evidence suggests that DCs contribute to the induction and/or maintenance of peripheral $\mathrm{T}_{\text {regs }}$, which in turn provide a negative-feedback signal to limit DC generation. However, it appears unlikely that DCs are absolutely required for $\mathrm{T}_{\text {reg }}$ homeostasis, or that DCs regulate $\mathrm{T}_{\text {regs }}$ preferentially compared to effector $\mathrm{T}$ cells.

\section{CONCLUDING REMARKS: TOWARD DC-BASED IMMUNOMODULATION}

The evidence reviewed above suggests essential but complex contributions of the DC lineage to almost every aspect of T lymphocyte homeostasis and responses (leaving aside the cross talk of DCs with many other cell types). These contributions depend on the activation state as well as on DC class (e.g., classical vs. plasmacytoid), subset (e.g., Batf3-dependent cross-presenting DCs vs. CD11b ${ }^{+}$DCs), and heterogeneity within the subset (e.g., Notch-dependent vs. independent $\mathrm{CD} 11 \mathrm{~b}^{+} \mathrm{DCs}$ ). In particular, DCs show extensive specialization and "division of labor" between the migratory "presenter" cells and the sessile "detector" cells generating local cytokine milieu. These complexities have been well appreciated in the development of clinical DC applications, in which different DC subsets may lead to different outcomes (Palucka et al. 2011).

As described above, no distinct tolerogenic subset or state of DCs has been clearly defined at the genetic level. Thus, therapeutic applications of DCs to induce tolerance may be relatively limited, and the advantage of DCs versus other (more abundant but potentially less immunogenic) cell types may have to be considered in every case. Nevertheless, certain clinical settings such as transplantation may provide fertile grounds for tolerogenic DC applications (Morelli and Thomson 2007).

On the other hand, the utility of DCs as cellular immunization vehicles and efficient "breakers" of tolerance remains unrivaled.
Among many potential uses of DC-based immunization, anticancer vaccines present the most promising venue (Palucka et al. 2010). Recent data suggest that endogenous DCs play an important role in antitumor immunity (Diamond et al. 2011; Fuertes et al. 2011), and that they may be functionally impaired by immunoevasive tumors (Engelhardt et al. 2012). Unleashing the capacity of DCs to present Ag and prime effector T cells to reverse the pathological tolerance to tumors may bring closer the ultimate success of cancer immunotherapy.

\section{ACKNOWLEDGMENTS}

This work is dedicated to the memory of Dr. Ralph Steinman, who not only championed dendritic cells and their clinical application, but also welcomed and supported junior researchers in the field. B.R.'s laboratory is supported by the American Asthma Foundation, the Lupus Research Institute, New York State Department of Health IDEA award N09G-22, and National Institutes of Health (NIH) grants AI067804, AI085439, and AI072571. K.L.L. is supported by NIH training grant AI007161.

\section{REFERENCES}

Alaniz RC, Sandall S, Thomas EK, Wilson CB. 2004. Increased dendritic cell numbers impair protective immunity to intracellular bacteria despite augmenting antigenspecific $\mathrm{CD}^{+}$T lymphocyte responses. J Immunol 172: 3725-3735.

Bachem A, Guttler S, Hartung E, Ebstein F, Schaefer M, Tannert A, Salama A, Movassaghi K, Opitz C, Mages HW, et al. 2010. Superior antigen cross-presentation and XCR1 expression define human $\mathrm{CD} 11 \mathrm{c}^{+} \mathrm{CD} 141^{+}$ cells as homologues of mouse $\mathrm{CD}^{+}$dendritic cells. $J$ Exp Med 207: 1273-1281.

Bar-On L, Birnberg T, Lewis KL, Edelson BT, Bruder D, Hildner K, Buer J, Murphy KM, Reizis B, Jung S. 2010 CX3CR $1^{+} \mathrm{CD} 8 \alpha^{+}$dendritic cells are a steady-state population related to plasmacytoid dendritic cells. Proc Natl Acad Sci 107: 14745-14750.

Bar-On L, Birnberg T, Kim KW, Jung S. 2011. Dendritic cellrestricted CD80/86 deficiency results in peripheral regulatory T-cell reduction but is not associated with lymphocyte hyperactivation. Eur J Immunol 41: 291-298.

Bell SJ, Rigby R, English N, Mann SD, Knight SC, Kamm MA, Stagg AJ. 2001. Migration and maturation of human colonic dendritic cells. J Immunol 166: 4958-4967.

Belz GT, Nutt SL. 2012. Transcriptional programming of the dendritic cell network. Nat Rev Immunol 12: 101-113. 
Bierly AL, Shufesky WJ, Sukhumavasi W, Morelli AE Denkers EY. 2008. Dendritic cells expressing plasmacytoid marker PDCA-1 are Trojan horses during Toxoplasma gondii infection. J Immunol 181: 8485-8491.

Birnberg T, Bar-On L, Sapoznikov A, Caton ML, CervantesBarragan L, Makia D, Krauthgamer R, Brenner O, Ludewig B, Brockschnieder D, et al. 2008. Lack of conventional dendritic cells is compatible with normal development and $\mathrm{T}$ cell homeostasis, but causes myeloid proliferative syndrome. Immunity 29: 986-997.

Bogunovic M, Ginhoux F, Helft J, Shang L, Hashimoto D, Greter M, Liu K, Jakubzick C, Ingersoll MA, Leboeuf M, et al. 2009. Origin of the lamina propria dendritic cell network. Immunity 31: 513-525.

Bonasio R, Scimone ML, Schaerli P, Grabie N, Lichtman AH, von Andrian UH. 2006. Clonal deletion of thymocytes by circulating dendritic cells homing to the thymus. Nat Immunol 7: 1092-1100.

Cervantes-Barragan L, Zust R, Weber F, Spiegel M, Lang KS, Akira S, Thiel V, Ludewig B. 2007. Control of coronavirus infection through plasmacytoid dendritic-cell-derived type I interferon. Blood 109: 1131-1137.

Cervantes-Barragan L, Lewis KL, Firner S, Thiel V, Hugues S Reith W, Ludewig B, Reizis B. 2012. Plasmacytoid dendritic cells control T-cell response to chronic viral infection. Proc Natl Acad Sci 109: 3012-3017.

Chen M, Wang YH, Wang Y, Huang L, Sandoval H, Liu YJ, Wang J. 2006. Dendritic cell apoptosis in the maintenance of immune tolerance. Science 311: 1160-1164.

Cisse B, Caton ML, Lehner M, Maeda T, Scheu S, Locksley R, Holmberg D, Zweier C, den Hollander NS, Kant SG, et al. 2008. Transcription factor E2-2 is an essential and specific regulator of plasmacytoid dendritic cell development. Cell 135: 37-48.

Collin M, Bigley V, Haniffa M, Hambleton S. 2011. Human dendritic cell deficiency: The missing ID? Nat Rev Immunol 11: 575-583.

Collins CB, Aherne CM, McNamee EN, Lebsack MD, Eltzschig H, Jedlicka P, Rivera-Nieves J. 2011. Flt3 ligand expands $\mathrm{CD}_{103}{ }^{+}$dendritic cells and FoxP $3^{+}$Tregulatory cells, and attenuates Crohn's-like murine ileitis. Gut doi: 10.1136/gutjnl-2011-300820.

Crozat K, Guiton R, Contreras V, Feuillet V, Dutertre CA, Ventre E, Vu Manh TP, Baranek T, Storset AK, Marvel J, et al. 2010a. The XC chemokine receptor 1 is a conserved selective marker of mammalian cells homologous to mouse $\mathrm{CD} 8 \alpha^{+}$dendritic cells. J Exp Med 207: $1283-$ 1292.

Crozat K, Guiton R, Guilliams M, Henri S, Baranek T, Schwartz-Cornil I, Malissen B, Dalod M. 2010b. Comparative genomics as a tool to reveal functional equivalences between human and mouse dendritic cell subsets. Immunol Rev 234: 177-198.

Darrasse-Jeze G, Deroubaix S, Mouquet H, Victora GD, Eisenreich T, Yao KH, Masilamani RF, Dustin ML, Rudensky A, Liu K, et al. 2009. Feedback control of regulatory T cell homeostasis by dendritic cells in vivo. J Exp Med 206: 1853-1862.

den Haan JM, Lehar SM, Bevan MJ. 2000. CD8 ${ }^{+}$but not $\mathrm{CD} 8^{-}$dendritic cells cross-prime cytotoxic $\mathrm{T}$ cells in vivo. J Exp Med 192: 1685-1696.
Denning TL, Norris BA, Medina-Contreras O, Manicassamy S, Geem D, Madan R, Karp CL, Pulendran B. 2011. Functional specializations of intestinal dendritic cell and macrophage subsets that control Th17 and regulatory $\mathrm{T}$ cell responses are dependent on the T cell/APC ratio, source of mouse strain, and regional localization. $J$ Immunol 187: 733-747.

Diamond MS, Kinder M, Matsushita H, Mashayekhi M, Dunn GP, Archambault JM, Lee H, Arthur CD, White JM, Kalinke U, et al. 2011. Type I interferon is selectively required by dendritic cells for immune rejection of tumors. J Exp Med 208: 1989-2003.

Dudziak D, Kamphorst AO, Heidkamp GF, Buchholz VR, Trumpfheller C, Yamazaki S, Cheong C, Liu K, Lee HW, Park CG, et al. 2007. Differential antigen processing by dendritic cell subsets in vivo. Science 315: 107-111.

Edelson BT, Kc W, Juang R, Kohyama M, Benoit LA, Klekotka PA, Moon C, Albring JC, Ise W, Michael DG, et al. 2010. Peripheral $\mathrm{CD}_{103^{+}}$dendritic cells form a unified subset developmentally related to $\mathrm{CD} 8 \alpha^{+}$conventional dendritic cells. J Exp Med 207: 823-836.

Edelson BT, Bradstreet TR, Hildner K, Carrero JA, Frederick KE, Kc W, Belizaire R, Aoshi T, Schreiber RD, Miller MJ, et al. 2011. CD8 $\alpha^{+}$dendritic cells are an obligate cellular entry point for productive infection by Listeria monocytogenes. Immunity 35: 236-248.

Engelhardt JJ, Boldajipour B, Beemiller P, Pandurangi $\mathrm{P}$, Sorensen C, Werb Z, Egeblad M, Krummel MF. 2012. Marginating dendritic cells of the tumor microenvironment cross-present tumor antigens and stably engage tumor-specific T cells. Cancer Cell 21: 402-417.

Fuertes MB, Kacha AK, Kline J, Woo SR, Kranz DM, Murphy KM, Gajewski TF. 2011. Host type I IFN signals are required for antitumor $\mathrm{CD} 8^{+} \mathrm{T}$ cell responses through CD8 $\alpha^{+}$dendritic cells. J Exp Med 208: 2005-2016.

Gallegos AM, Bevan MJ. 2004. Central tolerance to tissuespecific antigens mediated by direct and indirect antigen presentation. J Exp Med 200: 1039-1049.

Garbi N, Hammerling GJ, Probst HC, van den Broek M. 2010. Tonic T cell signalling and $\mathrm{T}$ cell tolerance as opposite effects of self-recognition on dendritic cells. Curr Opin Immunol 22: 601-608.

Gaspar M, May JS, Sukla S, Frederico B, Gill MB, Smith CM, Belz GT, Stevenson PG. 2011. Murid herpesvirus-4 exploits dendritic cells to infect B cells. PLoS Pathog 7: e1002346.

Geissmann F, Manz MG, Jung S, Sieweke MH, Merad M, Ley K. 2010. Development of monocytes, macrophages, and dendritic cells. Science 327: 656-661.

Ghosh HS, Cisse B, Bunin A, Lewis KL, Reizis B. 2010. Continuous expression of the transcription factor e2-2 maintains the cell fate of mature plasmacytoid dendritic cells. Immunity 33: 905-916.

Hadeiba H, Sato T, Habtezion A, Oderup C, Pan J, Butcher EC. 2008. CCR9 expression defines tolerogenic plasmacytoid dendritic cells able to suppress acute graft-versushost disease. Nat Immunol 9: 1253-1260.

Hadeiba H, Lahl K, Edalati A, Oderup C, Habtezion A, Pachynski R, Nguyen L, Ghodsi A, Adler S, Butcher EC. 2012. Plasmacytoid dendritic cells transport peripheral antigens to the thymus to promote central tolerance. Immunity 36: 438-450. 
Hambleton S, Salem S, Bustamante J, Bigley V, BoissonDupuis S, Azevedo J, Fortin A, Haniffa M, Ceron-Gutierrez L, Bacon CM, et al. 2011. IRF8 mutations and human dendritic-cell immunodeficiency. $N$ Engl J Med 365: $127-138$.

Hamme GE, Turer EE, Taylor KE, Fang CJ, Advincula R, Oshima S, Barrera J, Huang EJ, Hou B, Malynn BA, et al. 2011. Expression of A20 by dendritic cells preserves immune homeostasis and prevents colitis and spondyloarthritis. Nat Immunol 12: 1184-1193.

Hawiger D, Inaba K, Dorsett Y, Guo M, Mahnke K, Rivera M, Ravetch JV, Steinman RM, Nussenzweig MC. 2001. Dendritic cells induce peripheral $\mathrm{T}$ cell unresponsiveness under steady state conditions in vivo. J Exp Med 194: 769-779.

Hawiger D, Masilamani RF, Bettelli E, Kuchroo VK, Nussenzweig MC. 2004. Immunological unresponsiveness characterized by increased expression of CD5 on peripheral $\mathrm{T}$ cells induced by dendritic cells in vivo. Immunity 20: 695-705.

Hildner K, Edelson BT, Purtha WE, Diamond M, Matsushita H, Kohyama M, Calderon B, Schraml BU, Unanue ER, Diamond MS, et al. 2008. Batf3 deficiency reveals a critical role for $\mathrm{CD} 8 \alpha^{+}$dendritic cells in cytotoxic T cell immunity. Science 322: 1097-1100.

Hochweller K, Miloud T, Striegler J, Naik S, Hammerling GJ, Garbi N. 2009. Homeostasis of dendritic cells in lymphoid organs is controlled by regulation of their precursors via a feedback loop. Blood 114: 4411-4421.

Hochweller K, Wabnitz GH, Samstag Y, Suffner J, Hammerling GJ, Garbi N. 2010. Dendritic cells control T cell tonic signaling required for responsiveness to foreign antigen. Proc Natl Acad Sci 107: 5931-5936.

Hubert FX, Kinkel SA, Davey GM, Phipson B, Mueller SN, Liston A, Proietto AI, Cannon PZ, Forehan S, Smyth GK, et al. 2011. Aire regulates the transfer of antigen from mTECs to dendritic cells for induction of thymic tolerance. Blood 118: 2462-2472.

Irla M, Kupfer N, Suter T, Lissilaa R, Benkhoucha M, Skupsky J, Lalive PH, Fontana A, Reith W, Hugues S. 2010 MHC class II-restricted antigen presentation by plasmacytoid dendritic cells inhibits T cell-mediated autoimmunity. J Exp Med 207: 1891-1905.

Jaensson E, Uronen-Hansson H, Pabst O, Eksteen B, Tian J, Coombes JL, Berg PL, Davidsson T, Powrie F, JohanssonLindbom B, et al. 2008. Small intestinal $\mathrm{CD}_{103^{+}}$dendritic cells display unique functional properties that are conserved between mice and humans. J Exp Med 205: 2139-2149.

Jongbloed SL, Kassianos AJ, McDonald KJ, Clark GJ, Ju X, Angel CE, Chen CJ, Dunbar PR, Wadley RB, Jeet V, et al. 2010. Human CD141 ${ }^{+}(\text {BDCA-3) })^{+}$dendritic cells (DCs) represent a unique myeloid DC subset that cross-presents necrotic cell antigens. J Exp Med 207: 1247-1260.

Kasahara S, Clark EA. 2012. Dendritic cell-associated lectin 2 (DCAL2) defines a distinct CD8 $\alpha$-dendritic cell subset. J Leukoc Biol 91: 437-448.

Kim JM, Rasmussen JP, Rudensky AY. 2007. Regulatory T cells prevent catastrophic autoimmunity throughout the lifespan of mice. Nat Immunol 8: 191-197.
Kim SJ, Zou YR, Goldstein J, Reizis B, Diamond B. 2011. Tolerogenic function of Blimp-1 in dendritic cells. J Exp Med 208: 2193-2199.

Klein L, Hinterberger M, von Rohrscheidt J, Aichinger M. 2011. Autonomous versus dendritic cell-dependent contributions of medullary thymic epithelial cells to central tolerance. Trends Immunol 32: 188-193.

Knight SC, Balfour BM, O'Brien J, Buttifant L, Sumerska T, Clarke J. 1982. Role of veiled cells in lymphocyte activation. Eur J Immunol 12: 1057-1060.

Kool M, van Loo G, Waelput W, De Prijck S, Muskens F, Sze M, van Praet J, Branco-Madeira F, Janssens S, Reizis B, et al. 2011. The ubiquitin-editing protein A20 prevents dendritic cell activation, recognition of apoptotic cells, and systemic autoimmunity. Immunity 35: 82-96.

Kriegel MA, Rathinam C, Flavell RA. 2012. Pancreatic islet expression of chemokine CCL2 suppresses autoimmune diabetes via tolerogenic $\mathrm{CD} 11 \mathrm{c}^{+} \mathrm{CD} 11 \mathrm{~b}^{+}$dendritic cells. Proc Natl Acad Sci 109: 3457-3462.

Lacy-Hulbert A, Smith AM, Tissire H, Barry M, Crowley D, Bronson RT, Roes JT, Savill JS, Hynes RO. 2007. Ulcerative colitis and autoimmunity induced by loss of myeloid $\alpha \mathrm{v}$ integrins. Proc Natl Acad Sci 104: 15823-15828.

Lei Y, Ripen AM, Ishimaru N, Ohigashi I, Nagasawa T, Jeker LT, Bosl MR, Hollander GA, Hayashi Y, Malefyt Rde W, et al. 2011. Aire-dependent production of XCL1 mediates medullary accumulation of thymic dendritic cells and contributes to regulatory $\mathrm{T}$ cell development. J Exp Med 208: $383-394$.

Lewis KL, Caton ML, Bogunovic M, Greter M, Grajkowska LT, Ng D, Klinakis A, Charo IF, Jung S, Gommerman JL, et al. 2011. Notch2 receptor signaling controls functional differentiation of dendritic cells in the spleen and intestine. Immunity 35: 780-791.

Liu YJ. 2005. IPC: Professional type 1 interferon-producing cells and plasmacytoid dendritic cell precursors. Annu Rev Immunol 23: 275-306.

Liu K, Nussenzweig MC. 2010. Origin and development of dendritic cells. Immunol Rev 234: 45-54.

Liu K, Victora GD, Schwickert TA, Guermonprez P, Meredith MM, Yao K, Chu FF, Randolph GJ, Rudensky AY, Nussenzweig M. 2009. In vivo analysis of dendritic cell development and homeostasis. Science 324: 392-397.

Loschko J, Heink S, Hackl D, Dudziak D, Reindl W, Korn T, Krug AB. 2011a. Antigen targeting to plasmacytoid dendritic cells via Siglec-H inhibits Th cell-dependent autoimmunity. J Immunol 187: 6346-6356.

Loschko J, Schlitzer A, Dudziak D, Drexler I, Sandholzer N, Bourquin C, Reindl W, Krug AB. 2011b. Antigen delivery to plasmacytoid dendritic cells via BST2 induces protective T cell-mediated immunity. J Immunol 186: 67186725.

MacDonald KP, Munster DJ, Clark GJ, Dzionek A, Schmitz J, Hart DN. 2002. Characterization of human blood dendritic cell subsets. Blood 100: 4512-4520.

Manicassamy S, Reizis B, Ravindran R, Nakaya H, SalazarGonzalez RM, Wang YC, Pulendran B. 2010. Activation of $\beta$-catenin in dendritic cells regulates immunity versus tolerance in the intestine. Science 329: 849-853.

Martin-Gayo E, Sierra-Filardi E, Corbi AL, Toribio ML. 2010. Plasmacytoid dendritic cells resident in human 
thymus drive natural Treg cell development. Blood 115: 5366-5375.

Mashayekhi M, Sandau MM, Dunay IR, Frickel EM, Khan A, Goldszmid RS, Sher A, Ploegh HL, Murphy TL, Sibley LD, et al. 2011. CD $8 \alpha^{+}$dendritic cells are the critical source of interleukin-12 that controls acute infection by Toxoplasma gondii tachyzoites. Immunity 35: 249-259.

Matmati M, Jacques P, Maelfait J, Verheugen E, Kool M, Sze M, Geboes L, Louagie E, Guire CM, Vereecke L, et al. 2011. A20 (TNFAIP3) deficiency in myeloid cells triggers erosive polyarthritis resembling rheumatoid arthritis. Nat Genet 43: 908-912.

McDole JR, Wheeler LW, McDonald KG, Wang B, Konjufca V, Knoop KA, Newberry RD, Miller MJ. 2012. Goblet cells deliver luminal antigen to $\mathrm{CD} 103^{+}$dendritic cells in the small intestine. Nature 483: 345-349.

Melillo JA, Song L, Bhagat G, Blazquez AB, Plumlee CR, Lee C, Berin C, Reizis B, Schindler C. 2010. Dendritic cell (DC)-specific targeting reveals Stat 3 as a negative regulator of DC function. J Immunol 184: 2638-2645.

Merad M, Manz MG. 2009. Dendritic cell homeostasis. Blood 113: 3418-3427.

Mittag D, Proietto AI, Loudovaris T, Mannering SI, Vremec D, Shortman K, Wu L, Harrison LC. 2011. Human dendritic cell subsets from spleen and blood are similar in phenotype and function but modified by donor health status. J Immunol 186: 6207-6217.

Morelli AE, Thomson AW. 2007. Tolerogenic dendritic cells and the quest for transplant tolerance. Nat Rev Immunol 7: 610-621.

Naik SH, Sathe P, Park HY, Metcalf D, Proietto AI, Dakic A, Carotta S, O’Keeffe M, Bahlo M, Papenfuss A, et al. 2007. Development of plasmacytoid and conventional dendritic cell subtypes from single precursor cells derived in vitro and in vivo. Nat Immunol 8: 1217-1226.

Niess JH, Brand S, Gu X, Landsman L, Jung S, McCormick BA, Vyas JM, Boes M, Ploegh HL, Fox JG, et al. 2005. CX3CR1-mediated dendritic cell access to the intestinal lumen and bacterial clearance. Science 307: 254-258.

Ochando JC, Homma C, Yang Y, Hidalgo A, Garin A, Tacke F, Angeli V, Li Y, Boros P, Ding Y, et al. 2006. Alloantigenpresenting plasmacytoid dendritic cells mediate tolerance to vascularized grafts. Nat Immunol 7: 652-662.

Ohnmacht C, Pullner A, King SB, Drexler I, Meier S, Brocker T, Voehringer D. 2009. Constitutive ablation of dendritic cells breaks self-tolerance of CD4 T cells and results in spontaneous fatal autoimmunity. J Exp Med 206: 549559.

O'Keeffe M, Hochrein H, Vremec D, Pooley J, Evans R, Woulfe S, Shortman K. 2002. Effects of administration of progenipoietin 1, Flt-3 ligand, granulocyte colonystimulating factor, and pegylated granulocyte-macrophage colony-stimulating factor on dendritic cell subsets in mice. Blood 99: 2122-2130.

Onai N, Obata-Onai A, Schmid MA, Ohteki T, Jarrossay D, Manz MG. 2007. Identification of clonogenic common Flt $3^{+} \mathrm{M}-\mathrm{CSFR}^{+}$plasmacytoid and conventional dendritic cell progenitors in mouse bone marrow. Nat Immunol 8: 1207-1216.

Palucka K, Banchereau J, Mellman I. 2010. Designing vaccines based on biology of human dendritic cell subsets. Immunity 33: 464-478.
Palucka K, Ueno H, Banchereau J. 2011. Recent developments in cancer vaccines. J Immunol 186: 1325-1331.

Poulin LF, Salio M, Griessinger E, Anjos-Afonso F, Craciun L, Chen JL, Keller AM, Joffre O, Zelenay S, Nye E, et al. 2010. Characterization of human DNGR- $1^{+} \mathrm{BDCA}^{+}$ leukocytes as putative equivalents of mouse $\mathrm{CD} 8 \alpha^{+}$dendritic cells. J Exp Med 207: 1261-1271.

Poulin LF, Reyal Y, Uronen-Hansson H, Schraml B, Sancho D, Murphy KM, Hakansson UK, Ferreira Moita L, Agace WW, Bonnet D, et al. 2012. DNGR-1 is a specific and universal marker of mouse and human Batf3-dependent dendritic cells in lymphoid and non-lymphoid tissues. Blood doi: 10.1182/blood-2012-01-406967.

Probst HC, Lagnel J, Kollias G, van den Broek M. 2003. Inducible transgenic mice reveal resting dendritic cells as potent inducers of $\mathrm{CD}^{+} \mathrm{T}$ cell tolerance. Immunity 18: $713-720$.

Probst HC, McCoy K, Okazaki T, Honjo T, van den Broek M. 2005. Resting dendritic cells induce peripheral $\mathrm{CD} 8^{+} \mathrm{T}$ cell tolerance through PD-1 and CTLA-4. Nat Immunol 6: $280-286$.

Proietto AI, van Dommelen S, Zhou P, Rizzitelli A, D’Amico A, Steptoe RJ, Naik SH, Lahoud MH, Liu Y, Zheng P, et al. 2008. Dendritic cells in the thymus contribute to T-regulatory cell induction. Proc Natl Acad Sci 105: 1986919874.

Proietto AI, van Dommelen S, Wu L. 2009. The impact of circulating dendritic cells on the development and differentiation of thymocytes. Immunol Cell Biol 87: 39-45.

Reizis B, Bunin A, Ghosh HS, Lewis KL, Sisirak V. 2011. Plasmacytoid dendritic cells: Recent progress and open questions. Annu Rev Immunol 29: 163-183.

Sapoznikov A, Jung S. 2008. Probing in vivo dendritic cell functions by conditional cell ablation. Immunol Cell Biol 86: $409-415$.

Sathaliyawala T, O'Gorman WE, Greter M, Bogunovic M, Konjufca V, Hou ZE, Nolan GP, Miller MJ, Merad M, Reizis B. 2010. Mammalian target of rapamycin controls dendritic cell development downstream of Flt3 ligand signaling. Immunity 33: 597-606.

Scheinecker C, McHugh R, Shevach EM, Germain RN. 2002. Constitutive presentation of a natural tissue autoantigen exclusively by dendritic cells in the draining lymph node. J Exp Med 196: 1079-1090.

Schildknecht A, Brauer S, Brenner C, Lahl K, Schild H, Sparwasser T, Probst HC, van den Broek M. 2010. FoxP3 ${ }^{+}$ regulatory $\mathrm{T}$ cells essentially contribute to peripheral $\mathrm{CD} 8^{+} \mathrm{T}$-cell tolerance induced by steady-state dendritic cells. Proc Natl Acad Sci 107: 199-203.

Schulz O, Jaensson E, Persson EK, Liu X, Worbs T, Agace WW, Pabst O. 2009. Intestinal $\mathrm{CD}_{103}{ }^{+}$, but not $\mathrm{CX} 3 \mathrm{CR} 1^{+}$, antigen sampling cells migrate in lymph and serve classical dendritic cell functions. J Exp Med 206: $3101-3114$.

Segura E, Valladeau-Guilemond J, Donnadieu MH, SastreGarau X, Soumelis V, Amigorena S. 2012. Characterization of resident and migratory dendritic cells in human lymph nodes. J Exp Med 209: 653-660.

Sela U, Olds P, Park A, Schlesinger SJ, Steinman RM. 2011. Dendritic cells induce antigen-specific regulatory T cells that prevent graft versus host disease and persist in mice. $J$ Exp Med 208: 2489-2496. 
K.L. Lewis and B. Reizis

Shakhar G, Lindquist RL, Skokos D, Dudziak D, Huang JH, Nussenzweig MC, Dustin ML. 2005. Stable T cell-dendritic cell interactions precede the development of both tolerance and immunity in vivo. Nat Immunol 6: 707714.

Steinman RM. 2007. Lasker Basic Medical Research Award. Dendritic cells: Versatile controllers of the immune system. Nat Med 13: 1155-1159.

Steinman RM. 2012. Decisions about dendritic cells: Past, present, and future. Annu Rev Immunol 30: 1-22.

Steinman RM, Witmer MD. 1978. Lymphoid dendritic cells are potent stimulators of the primary mixed leukocyte reaction in mice. Proc Natl Acad Sci 75: 5132-5136.

Steinman RM, Hawiger D, Nussenzweig MC. 2003. Tolerogenic dendritic cells. Annu Rev Immunol 21: 685-711.

Stranges PB, Watson J, Cooper CJ, Choisy-Rossi CM, Stonebraker AC, Beighton RA, Hartig H, Sundberg JP, Servick S, Kaufmann G, et al. 2007. Elimination of antigen-presenting cells and autoreactive T cells by Fas contributes to prevention of autoimmunity. Immunity 26: 629-641.

Suffner J, Hochweller K, Kuhnle MC, Li X, Kroczek RA, Garbi N, Hammerling GJ. 2010. Dendritic cells support homeostatic expansion of Foxp $3^{+}$regulatory $\mathrm{T}$ cells in Foxp3.LuciDTR mice. J Immunol 184: 1810-1820.

Swee LK, Bosco N, Malissen B, Ceredig R, Rolink A. 2009. Expansion of peripheral naturally occurring T regulatory cells by Fms-like tyrosine kinase 3 ligand treatment. Blood 113: 6277-6287.

Swiecki M, Colonna M. 2010. Unraveling the functions of plasmacytoid dendritic cells during viral infections, autoimmunity, and tolerance. Immunol Rev 234: 142-162.

Swiecki M, Gilfillan S, Vermi W, Wang Y, Colonna M. 2010. Plasmacytoid dendritic cell ablation impacts early interferon responses and antiviral NK and $\mathrm{CD}^{+} \mathrm{T}$ cell accrual. Immunity 33: 955-966.

Takagi H, Fukaya T, Eizumi K, Sato Y, Sato K, Shibazaki A, Otsuka H, Hijikata A, Watanabe T, Ohara O, et al. 2011. Plasmacytoid dendritic cells are crucial for the initiation of inflammation and $\mathrm{T}$ cell immunity in vivo. Immunity 35: 958-971.

Takeda K, Clausen BE, Kaisho T, Tsujimura T, Terada N, Forster I, Akira S. 1999. Enhanced Th1 activity and development of chronic enterocolitis in mice devoid of
Stat 3 in macrophages and neutrophils. Immunity 10: 39-49.

Tarbell KV, Yamazaki S, Olson K, Toy P, Steinman RM. 2004. $\mathrm{CD} 25^{+} \mathrm{CD}^{+} \mathrm{T}$ cells, expanded with dendritic cells presenting a single autoantigenic peptide, suppress autoimmune diabetes. J Exp Med 199: 1467-1477.

Teichmann LL, Ols ML, Kashgarian M, Reizis B, Kaplan DH, Shlomchik MJ. 2010. Dendritic cells in lupus are not required for activation of T and B cells but promote their expansion, resulting in tissue damage. Immunity 33: 967-978.

Travis MA, Reizis B, Melton AC, Masteller E, Tang Q, Proctor JM, Wang Y, Bernstein X, Huang X, Reichardt LF, et al. 2007. Loss of integrin $\alpha_{v} \beta_{8}$ on dendritic cells causes autoimmunity and colitis in mice. Nature 449: 361-365.

Varol C, Vallon-Eberhard A, Elinav E, Aychek T, Shapira Y, Luche H, Fehling HJ, Hardt WD, Shakhar G, Jung S. 2009. Intestinal lamina propria dendritic cell subsets have different origin and functions. Immunity 31: 502512.

Varol C, Zigmond E, Jung S. 2010. Securing the immune tightrope: Mononuclear phagocytes in the intestinal lamina propria. Nat Rev Immunol 10: 415-426.

Villadangos JA, Young L. 2008. Antigen-presentation properties of plasmacytoid dendritic cells. Immunity 29: 352-361.

Vollstedt S, O’Keeffe M, Odermatt B, Beat R, Glanzmann B, Riesen M, Shortman K, Suter M. 2004. Treatment of neonatal mice with Flt3 ligand leads to changes in dendritic cell subpopulations associated with enhanced IL12 and IFN- $\alpha$ production. Eur J Immunol 34: 1849-1860.

Yamazaki S, Iyoda T, Tarbell K, Olson K, Velinzon K, Inaba K, Steinman RM. 2003. Direct expansion of functional $\mathrm{CD} 25^{+} \mathrm{CD}^{+}{ }^{+}$regulatory $\mathrm{T}$ cells by antigen-processing dendritic cells. J Exp Med 198: 235-247.

Yamazaki S, Dudziak D, Heidkamp GF, Fiorese C, Bonito AJ, Inaba K, Nussenzweig MC, Steinman RM. 2008. CD8 ${ }^{+-}$ $\mathrm{CD}_{205}{ }^{+}$splenic dendritic cells are specialized to induce Foxp $3^{+}$regulatory T cells. J Immunol 181: 6923-6933.

Zhang M, Tang H, Guo Z, An H, Zhu X, Song W, Guo J, Huang X, Chen T, Wang J, et al. 2004. Splenic stroma drives mature dendritic cells to differentiate into regulatory dendritic cells. Nat Immunol 5: 1124-1133. 


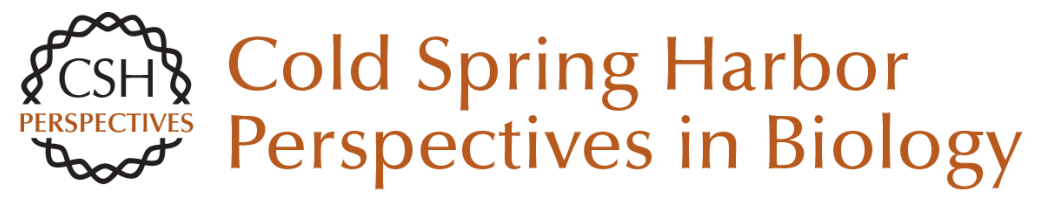

\section{Dendritic Cells: Arbiters of Immunity and Immunological Tolerance}

Kanako L. Lewis and Boris Reizis

Cold Spring Harb Perspect Biol 2012; doi: 10.1101/cshperspect.a007401

Subject Collection Immune Tolerance

Regulatory T Cells and Immune Tolerance in the Intestine

Oliver J. Harrison and Fiona M. Powrie

Dendritic Cells: Arbiters of Immunity and

Immunological Tolerance

Kanako L. Lewis and Boris Reizis

Current and Future Immunomodulation Strategies

to Restore Tolerance in Autoimmune Diseases Jeffrey A. Bluestone and Hélène Bour-Jordan

T-Cell Tolerance: Central and Peripheral Yan Xing and Kristin A. Hogquist

Central B-Cell Tolerance: Where Selection Begins Roberta Pelanda and Raul M. Torres

The Immunogenetic Architecture of Autoimmune Disease

An Goris and Adrian Liston
Regulatory T Cells and Immune Tolerance in the Intestine

Oliver J. Harrison and Fiona M. Powrie

Microbiota and Autoimmunity

Alexander V. Chervonsky

Treg Cells, Life History, and Diversity Christophe Benoist and Diane Mathis

Infectious (Non)tolerance--Frustrated

Commensalism Gone Awry? Jesse C. Nussbaum and Richard M. Locksley

Historical Overview of Immunological Tolerance Ronald H. Schwartz

Natural Killer Cell Tolerance: Control by Self or

Self-Control?

Baptiste N. Jaeger and Eric Vivier

For additional articles in this collection, see http://cshperspectives.cshlp.org/cgi/collection/

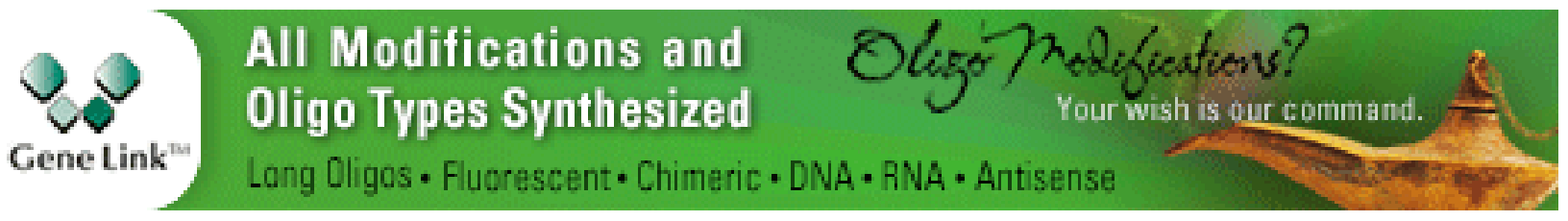

Copyright @ 2012 Cold Spring Harbor Laboratory Press; all rights reserved 